\title{
Some Aspects of the Implementation of Actions Plans for Noise Prevention and Reduction in Urban Areas
}

\author{
Vasile Bacria $^{1}$, Nicolae Herisanu ${ }^{1 *}$ \\ ${ }^{1}$ Faculty of Mechanics/Department of Mechanics and Strength of Materials, University Politehnica Timisoara, Timisoara \\ (Romania) \\ Following the analysis of noise maps for road, rail and industrial traffic on Lden and Ln as well as the corresponding \\ conflict maps, action plans were prepared to prevent and reduce noise in the mentioned areas of the urban environment. \\ They set out the measures to be taken, the completion dates and the number of people benefiting from the noise reduction. \\ Measures to reduce urban noise have also been established for the long-term strategy. These were performed with an \\ application to the Timișoara city. Subsequently, the administrative bodies of the municipality proceeded to implement the \\ measures provided in the action plans. The paper refers to some considerations on their implementation highlighting the \\ resulting effects.
}

Keywords: Heavy machinery, Mechanical engineering, Civil engineering

\section{INTRODUCTION}

The main sources of noise in the urban environment are the means of transport participating in the naval, air, rail, road traffic and industrial activities. The noise generated by these sources affect the life and health of members of the urban community. In this sense, research on noise and vibration pollution produced by road traffic has been carried out in Timisoara since 1996 [5]. On the other hand, the European Parliament and the Council ofthe European Union, of which Romania is a member, are concerned with ensuring a high level of health and environmental protection for the inhabitants of all Union countries, and Directive 2002/49/EC was adopted on 25 June 2002 [6], its main task being to create a common basis for all European Union states for the urban management of environmental noise. which:

Some important aspects are provided, among

a) Monitoring environmental issues by involving the competent authorities of the member states in the creation of strategic noise maps for roads, railways, airports, industrial areas and important agglomerations using harmonized noise indicators Lden and Ln. Thesemaps will be used to assess the number of people affected by noise throughout the European Union

b) Informing and consulting the public on exposureto noise, its effects and the measures that can be taken to combat it.

c) Development of noise management action plans to prevent and reduce environmental noise in order toprotect human health and conserve quiet areas

d) Ensuring the effective participation of the authorities in the whole process of planning activities. In this regard, all Member States of the European Union have been concerned with the development by 30 June 2007 of strategic noise maps for all urban areas with more than 250000 inhabitants and for all major areas with more than 6 million vehicles in traffic per year, major railways with over 60000 trains in traffic per year and major airports located on their territory.
On the basis of the noise maps drawn up by 18 July 2008 , the competent bodies drew up the action plans on noise prevention and reduction in the city of Timișoara, for which the acoustic map was drawn up [10]. According to Directive 2002/49/EC, the strategic noise map and action plans on the prevention and reduction of ambient noise for those agglomerations must be reviewed every 5 years. For the city of Timișoara, the strategic noise and conflict map were updated in 2013 [14]. Following the analysis of these acoustic maps, the authors of this paper have drawn up action plans on preventing and reducing environmental noise in Timisoara.

The action plans have been drawn up on the basis of the requirements of Directive 2002/49/EC [6]. In this sense, we will illustrate the reflection of theserequirements in the action plans prepared for the city of Timișoara, presenting considerations on their implementation and highlighting the resulting effects.

\section{INFORMATION OBTAINED BY NOISE MAPPING}

The authority responsible for the implementation of noise mapping and action plans for the prevention and reduction of ambient noise in the city of Timișoara is the City Hall. Timişoara is the residence of Timiş County, the largest city in western Romania, a very important economic, historical, social and cultural centre covering an area of 130 square $\mathrm{km}$ and having on January 1, 2020 a population of 306466 inhabitants. Also, Timisoara is a strong economic and industrial pole of the country, being crossed by the main national and European roads and railways, with an international airport. The strategic noise map and the action plans for the prevention and reduction of noise in urban areas, specifically in the city of Timișoara, were prepared taking into account all legislative regulations contained in the following normative acts: H.G. $321 / 2005$ republished onenvironmental noise assessment and management; O.M. no. 1830/2007 on the approval of the guide on the development, analysis and evaluation of strategic noisemaps; O.M. 152/558/1119/532/2008 for the approval ofthe guide on the adoption of limit values and 
their application when drawing up action plans for the Lden and $\mathrm{Ln}$ indicators for road, rail and air traffic noise and noise of industrial activities.

The indicators Lden and Ln are used to characterize the permissible limit values of ambient noise. The Lden indicator is defined by:

$$
L_{d e n}=101 \mathrm{~g} \frac{1}{24}\left[12 \cdot 10^{\frac{L d}{10}}+4 \cdot 10^{\frac{L e+5}{10}}+8 \cdot 10^{\frac{L n+10}{10}}\right]
$$

where $\mathrm{Ld}$ is the long-term noise existing on a 12-hour day during a year between 07.00-19.00, Le is the long-term noise level measured in a four-hour evening during a year between 19.00-23.00, $\mathrm{Ln}$ is the long-term noise level for an 8-hour night between 23.00 and 7.00.

Based on the order of the Minister of Environment and Sustainable Development number 152/13.02.2008, the maximum allowed values for the indicators Lden and Ln target values to be reached are those presented in table 1 .

Table 1: Admissible limits for noise indicators

\begin{tabular}{|c|c|c|c|c|c|}
\hline \multicolumn{3}{|c|}{ Lden [dB(A)] } & \multicolumn{3}{c|}{ Ln $[\mathrm{dB}(\mathrm{A})]$} \\
\hline $\begin{array}{l}\text { Source } \\
\text { of noise }\end{array}$ & Target & $\begin{array}{l}\text { Max. } \\
\text { value }\end{array}$ & $\begin{array}{l}\text { Source } \\
\text { of noise }\end{array}$ & Target & $\begin{array}{c}\text { Max. } \\
\text { value }\end{array}$ \\
\hline Roads & 65 & 70 & Roads & 50 & 60 \\
\hline Railways & 65 & 70 & Railways & 50 & 60 \\
\hline Airports & 65 & 70 & Airports & 50 & 60 \\
\hline Industry & 60 & 65 & Industry & 50 & 55 \\
\hline
\end{tabular}

For the elaboration of the action plans were used the data highlighted by the strategic noise maps and conflict maps prepared in 2013 regarding the noise produced by road traffic, rail traffic (train, tram), air traffic and industrial activities, all in Lden and Ln regime. [14]. The analysis of these data showed that there were a number of 24294 people exposed to noise above the allowable limit of $65 \mathrm{~dB}$ for the $\mathrm{Lz}$ indicator, respectively 45562 people exposed to a level of over $50 \mathrm{~dB}$ for the $\mathrm{Ln}$ indicator due to road traffic, five people exposed to noise level above the limit of $65 \mathrm{~dB}$ for the Lden indicator and 535 persons exposed at the level of over $50 \mathrm{~dB}$ for the $\mathrm{Ln}$ indicator due to rail traffic (tram), as well as 10 people exposed to the noise level above the limit of $60 \mathrm{~dB}$ for the Lden indicator, respectively 99 people exposed to noise level over $50 \mathrm{~dB}$ for the $\mathrm{Ln}$ indicator due to industrial activities.

It also turned out that there are no people exposed to a noise level above the $65 \mathrm{~dB}$ limit for Lden and over $50 \mathrm{~dB}$ for Ln due to rail traffic (tram) and air traffic. At the same time, the arteries of road traffic with the most pronounced impact on the exposure of the population to noise were identified. Thus, on 24 of them, the Lden noise level exceeded $70 \mathrm{~dB}$, on 29 it reached $70-75 \mathrm{~dB}$, and on 19 it reached values of 65-70 dB. From the presented data results that the noise pollution in Timișoara city was in a relatively good situation. This is also due to the fact that the local administration has been concerned with reducing noise in the city since 1996, when based on research contracts he collaborated with the research team in the department of mechanics and vibrations at the Faculty of Mechanics of the Polytechnic University of Timişoara (a group that includes the authors of the paper) in the issue of identifying noise sources on the territory of the city and reducing its level. In this sense, since 2006 the research team has prepared by measurements the first noise map of Timișoara, this having priority character in Romania.

According to Directive 2002/49/EC [6], action plans must be drawn up with the participation of the public and the public should be informed on their implementation. For this, in the first phase the public opinion was consulted through a questionnaire that was filled in individually by various persons residing in the city of Timisoara, including questions related to the position of housing in relation to the traffic artery, if disturbed by street noise, whether the noise affected his health and in what way, as well as proposals to reduce the noise produced by means of transport and other sources. From the synthesis of the answers, one obtained the following:

$-72.4 \%$ of dwellings are located in the front area and $27.6 \%$ in screened buildings

- while traveling in the city, $34.5 \%$ of Timisoara residents are disturbed, $24.1 \%$ in homes, $34.5 \%$ in the city and housing and $6.9 \%$ are disturbed

- the noise affected the health of $17.2 \%$ of those surveyed, causing them a state of stress and headache.

The respondents made proposals to reduce the noise produced by means of transport and other sources in the urban environment. Among these:

- public transport should be made free of charge, to discourage individual transport

- construction of city bypasses

- elimination of heavy vehicles from urban traffic

- reducing traffic intensity

- construction of noise-proof panels and manufacture of absorbent asphalt

- creation of green areas consisting of ornamental trees

- the purchase of new, quiet means of public transport

These proposals, together with the data resulting from the elaboration of the strategic noise and conflict maps were used for the elaboration of the action plans, which for the information of the inhabitants were posted on the official website of the Timișoara City Hall ensuring the conditions to appear also observations of public opinion.

It should be mentioned that prior to drawing up the action plans, the local administration of Timișoara being concerned with reducing noise in the city since 1996, implemented some reduction measures such as: restoring the infrastructure and superstructure of the tramway on a large part of it, largely improving the road traffic in the city and modernizing the intersections, equipping the public transport base with quieter means of transport, limiting the speed on certain traffic arteries and using speed bumps, limiting the access of large vehicles in the central area, restricting the access of certain vehicles in some areas of the city, introducing one-way on some of the traffic arteries, streamlining traffic, making green protective curtains, making an antiphonal screen on one of the traffic arteries, investigating the absorbent effects of rubber asphalt in order to implement as a solution to reduce traffic noise, the construction of the bypass in the north-eastern part of the city, the encouragement and support of the tenants for the use of thermal and sound insulation system, etc.

Following the values presented above, it results that although these measures have been implemented, there are still areas in the city where the permissible noise level limits mentioned in table 1 are exceeded. In this sense, it was 
necessary to identify and investigate the causes of this condition and to establish measures to normalize them.

\section{NOISE GENERATING SOURCES IN URBAN AREAS}

The state of noise pollution of the urban environment is due to the noise generated by urban, railway, air traffic and industrial activities. Each of them highlights specific sources.

At the means of road transport, the propulsion engine, the transmission system, the braking system, the running and the air resistance to advance generate noise. The resulting noise level depends on the composition and intensity of the traffic, the speed of the vehicles, their operating condition, as well as the nature and condition of the road.

For rail vehicles, the causes of noise are bumps, curves and road elasticity, play at the ends of the rails, jerking and braking, variations in speed, etc. In aircraft, the main sources of noise are internal combustion engines, propeller jet engines, turbo engines.

Noise and vibration in the means of shipping are generated by main and auxiliary engines, generators and electric motors, propellers, cooling pumps, oil, fuel, turbochargers, current converters, fans, wave blows, etc.

In the case of industrial activities, noises are produced by collision phenomena in the case of body interaction, friction on contact surfaces, aerodynamic turbulence, forced oscillations of solid bodies, the action of variable electromagnetic forces, vibration of membraneshaped parts and pulsating pressure in hydrostatic operating installations during mechanical, electromagnetic, aerodynamic and hydrostatic processes.

The noise generated by these sources bothers a large part of the population. It is enough to have a noise with the equivalent level of $75 \mathrm{~dB}$ per day to disturb $80 \%$ of the population [4]. In addition, it causes damage to the human auditory organ and various organs and apparatus of the body. Noise is very harmful to the human nervous system producing psychophysiological changes, for blood circulation, produces sleep disorders, negatively affects the visual function and endocrine glands producing biochemical disorders.

Due to the noise, hearing fatigue, sound trauma and general fatigue of the body occur. Noise also has a negative influence on physical and intellectual work that requires a focus of attention, reduces work productivity and speech intelligibility [1], [2]. In order to prevent these harmful effects of noise, the characteristic noise indicators Lden and Ln must not exceed in the urban environment the values presented in Table 1. If values exceeding these permissible limits are obtained, then noise reduction methods must be established and implemented.

\section{NOISE REDUCTION METHODS}

In establishing the specific methods in this case, we start from the fact that measures can be taken to reduce noise directly at the source or on the transmission route. have a quiet operation, proper technical condition and correct handling. Taking into account that the noise is influenced by the number and nature of the sources, restrictions are indicated for the intensity and composition of the traffic as well as the reduction of the maximum speed limit of the vehicles. Some elements of detail that highlight how these parameters influence the level of noise generated by the means of transport participating in road traffic can be traced in [4].

To reduce running noise, one can use the replacement of ordinary asphalt with rubberized asphalt. This helps to reduce noise by 1 to $6 \mathrm{~dB}$ depending on the speed of the vehicles. A more pronounced reduction is made for sounds whose frequencies are in the bands with a centre frequency of $1 \mathrm{~Hz}$ and $2 \mathrm{~Hz}$ in the case of higher vehicle speeds [15]. As a significant contribution to the generation of a high-level noise in the urban environment has the means of transport in transit, it is necessary to eliminate their presence by building bypasses for the city.

The noise produced by trams can be actively reduced by ensuring their proper technical and functional condition as well as by creating paths according to advanced technologies, installing between the runway and sleepers an effective insulating layer and planting grass in the space between the lines. The noise level produced by the trams is also influenced by the way the driving manoeuvres are performed, which must be as appropriate as possible.

With regard to the reduction directly to the source of the noise produced by the means of railway transport, this can be achieved by ensuring the use of means with good technical condition running on roads in perfect condition, they must be checked permanently and the defects remedied.

The reduction of the noise produced by the industrial activities directly at the source implies the realization within each industrial unit of the diminution of the noise produced by the main machine parts, by the aggregates of the machine tools and industrial equipment and by the technological processes. Inside the industrial halls, the soundproofing of the workplaces, the rational location of the noise sources, their casing and shielding, as well as the acoustic arrangement of the interior of the halls must be performed. At the same time, a rational location of the industrial rooms inside the industrial units and of them within the urban complexes must be made.

To reduce the noise produced by cars, trams, trains, planes at airports and passive industrial activities in the urban environment, acoustic screens and protection areas (green areas) can be created between residential neighbourhoods and roads, airports and industrial units, as well as increasing the distances between them. Some elements of correlation between the geometric characteristics of acoustic screens, their positioning as well as the source and receiver and the attenuation achieved can be traced in [1], [2], [3], [4]. The methods presented in this section can be used to choose solutions for drawing up action plans.

\section{ACTION PLANS}

Although measures were taken in the city of Timişoara to reduce the noise produced by road traffic before the adoption of the European Directive 2002/49/EC, the noise problem was still not solved. An important achievement is the construction of the bypass in the north-eastern part of the city. However, this must be 
continued with the construction of the bypass in the southeastern part. In this way, the vehicles in transit would be eliminated from the urban traffic. At the same time, the development of urban traffic in Timișoara is greatly influenced by the street configuration of the city which is of radial ring type, better structured at north of the Bega canal and less outlined in the south, to which is added the fact that the city is crossed from east to west by the railway line. Outside the central area there is an insufficient number of crossings, which does not allow the closure of the ring links between the areas on either side of the two obstacles. This makes the existing bridges over the Bega, the underpass viaducts and the corrective traffic arteries very crowded. In fact, the Bega canal and the railway are the two important obstacles that affect the continuity of the road network due to the insufficient number of bridges and passages. This is proved by the values recorded by the indicators Lden and Ln on the 24 traffic arteries on which the first indicator exceeded $75 \mathrm{~dB}$.

The configuration of the road network in Timișoara city presents some deficiencies in its structuring, the absence of collector arteries with four traffic lanes, as well as the inadequate capacity of some intersections and stationary traffic. The development of traffic in Timişoara can be done by building bypasses that would take over transit traffic, the development of public transport, parking networks, ensuring quiet means of transport, extending sidewalks in the central area, etc. The measures proposed to reduce the noise on the traffic arteries on which the limit values of the indicators Lden and Ln were exceeded were established in accordance with the traffic study for the city of Timişoara [13]. It contains the analysis of the current traffic, the elaboration of the proposals to improve the traffic and the plan of organization of the traffic. The traffic organization plan is identified by the road network plan, zoning, the graph associated with the major traffic network, traffic regulations, traffic light intersections, routes of transport lines, general orientation signalling, signalled routes for freight traffic and passengers and the classification of streets into categories.

This plan was improved in accordance with the traffic forecast and with the inclusion of the changes brought by the traffic regulations adopted by the Timișoara City Hall. In order to reduce the ambient noise, the strategic noise and conflict maps of the city of Timișoara corresponding to the indicators Lden and Ln were studied. After analysing these maps and taking into account the noise reduction methods in the urban environment presented above, 6 action plans for reducing road traffic noise, an action plan for reducing noise from rail traffic and an action plan to reduce noise generated by industrial activities were drawn up. They provided for:

a) modernization of 4 intersections of traffic arteries

b) location of acoustic screens between road traffic arteries and residentil areas on 14 traffic arteries the city

c) construction of the bypass in the southern part of

d) opening of traffic ring 4 from the traffic organization plan in Timişoara city

e) replacement of ordinary asphalt with rubberized asphalt on six traffic arteries

f) creation of green protection areas between the traffic arteries and the blocks of flats on 60 traffic arteries g) implementation of the building envelope program and installation of soundproof doors and windows

h) Location of acoustic screens between the train track and the blocks of flats in the area of three streets

i) reduction of the noise level inside the industrial premises and on the transmission route from the arteries to the inhabited areas.

Based on the estimates, it resulted that following the application of the elaborated action plans, 14459 people benefit from the reduction of the noise level in the regime of Lden and in the regime of Ln 18892 persons. The action plans also contained the delimitation of the quiet areas of the city as well as the actions that the authorities intend to undertake in the next five years.

\section{ESTABLISHING A LONG-TERM STRATEGY}

The action plans foreseen for a period of 5 years from the date of elaboration had to be complemented with the long-term strategy which includes the long-term vision of noise reduction. However, this requires good planning. Based on the noise maps prepared, the urban plans can be adjusted so as to ensure that no new buildings are built in areas with a high noise impact and no new industrial noisegenerating units are located near residential or quiet areas. Also, the planning of activities for noise prevention and conservation of quiet areas is feasible to be drawn up in the long-term strategy point according to the development strategy "Vision Timisoara 2030 - support for the development of a sustainable concept for the infrastructure of Timisoara", developed by Timișoara City Hall in collaboration with the Polytechnic University of Timișoara and the Fraunhofer Stuttgart Institute considered that environmental aspects should be integrated into other areas as much as possible.

The Vision 2030 concept must ensure in the city of Timișoara and in its peri-urban area an integrated transport system with additional services and increased comfort. The conditions of solid connections with the surrounding areas will be created, respectively the premises of a sustainable economic and social development will be generated. Regarding the objectives of the projects provided in the long-term strategy, the noise reduction measures can be highlighted as follows: construction of a closed bypass of Timișoara, closure of road rings, construction of uneven traffic jams, construction of 5 bridges over the Bega canal, the development of the network for non-motorized transport, the application of a layer of rubber asphalt on a significant number of traffic arteries in the penetration areas and inside the city of Timișoara, the installation of acoustic screens between traffic arteries and residential neighbourhoods, schools, hospitals, kindergartens, universities, further rehabilitation of traffic arteries, traffic flow obtained by traffic lights, one-way streets, new arteries, car and pedestrian walkways, establishment and increase of the density of alignment plantations, conservation and expansion of public green spaces and preserving the green character of existing areas individual targets, elimination of the surface railway transport line between Timişoara Nord and Timişoara Est stations, replacement of surface transport by underground by building metro lines with connections between important areas of the city, refurbishment and economic conversion 
for existing industrial areas, increasing competitiveness based on the promotion of new, creative and ecological industries, the realization of massive tree plantations in residential areas and residential neighbourhoods, the completion of the program of thermal rehabilitation and sound insulation of buildings by enveloping and installation of windows and soundproof doors, North Station arrangement, elimination of stationary traffic by creating underground and above- ground parking lots, redevelopment of the Bega canal, rehabilitation of tramway lines, replacement of new means of transport with the purchase of 100 trams and 100 electric buses, complex rehabilitation and modernization of all neighbourhoods at the level of roads, sidewalks, parking lots, bike lanes, green spaces, play trains, sports venues, construction of a new tram line between Gara de Nord and Children's Hospital, transformation of the Metropolitan Cathedral area into a pedestrian space by underpass, construction of new car passages and widening of existing ones, refurbishment of the traffic ring 1 and the construction of Traffic Rings 2, 3 and 4, the construction of two above-ground parking lots, the construction of a park of 5000 square meters, etc. Completion deadlines have been set for these objectives. At the same time, the local public authorities had to take care of preserving the quiet areas on the territory of the city by applying and extending the appropriate measures. It was estimated that by implementing the long-term strategy, 8349 people will benefit from the reduction of the noise level Ln and 15288 people will benefit from the reduction of the noise level Lden.

\section{CONSIDERATIONS REGARDING THE IMPLEMENTATION OF ACTION PLANS}

After drawing up the action plans and the long-term strategy, the key issue was their implementation. In this sense, in order to reduce the noise produced by road traffic, four important intersections of traffic arteries located in the central area of Timisoara were rearranged, the South East belt of the city with a length of $27 \mathrm{~km}$ will be completed by the end of 2022, the usual asphalt was also replaced on a significant number of traffic arteries, the program of enveloping buildings and the installation of soundabsorbing doors and windows was continued, as well as the creation of green protection areas between traffic arteries and apartment blocks. In order to streamline the road traffic between the southern and northern part of Timişoara, over the Bega canal and the railway, crossing passages and bridges were widened. In order to reduce the noise level produced by the means of transport, the pedestrian traffic was arranged, the use of bicycles and scooters by restoring the sidewalks on the side of the streets and especially the bicycle tracks. The creation of a green protection zone between the railway and the neighbouring inhabited areas contributes to their protection against the noise generated by the railway traffic. Regarding the noise generated by industrial activities to reduce the acoustic effects on people in inhabited buildings, it was ensured that the industrial units were not located near them, had an environmental permit, and green protection areas were planted between industrial and inhabited units.

In order to obtain a new quiet area, it started to implement noise reduction measures in the respective area: modernization of the neighbouring street, imposing speed restrictions, complementing the existing living degree with a curtain of vegetation in several steps. Given the condition and improper operation of a large number of trams and noise-generating buses, it was proceeded to purchase 100 new trams and 100 new electric buses to be received. In order to eliminate the stationary traffic, underground car parks have been built and two above- ground car parks are to be built. The Bega canal was redeveloped in order to capitalize on its naval potential, which will contribute to the decongestion of road and rail traffic and thus to the reduction of noise levels in urban areas. For a large number of streets, the one-way street was introduced, which allowed, in addition to a good organization of road traffic also obtaining parking spaces. The implementation of these measures contributes to reducing the level of urban noise, their efficiency will be highlighted by new measurements and experimental determinations in the near future.

\section{REFERENCES}

[1] M. Grumăzescu, A. Stan and N. Wegener, “Combaterea zgomotului si vibrațiilor”, Editura Tehnică,București (Romania), (1964)

[2] E.Ia Iudin, "Izolarea împotriva zgomotului", Editura Tehnică, București (Romania), (1968)

[3] Stadtbauliche Larmfild. Hinweise fur die Bauleitplanung, Baden Wurtenberg, Innenministrium, (Germany), (1991)

[4] Larmbekamfung in Wien. Envichlung Stand Tendenzen Magistrstsabteilung 22 Umweltschutz

[5] Gh. Sila, L. Brindeu, M. Toader, V. Bacria, N. Herisanu, M. Suciu, "Cercetari privind poluarea prin zgomote si vibratii produse de traficul rutier in municipiulTimisoara", Ses. Comunicari de Acustica a Academiei Romane, Caiet 26, Bucuresti, (Romania), 15-16 October 1996, pp.81-84 (1996)

[6] Directive 2002/49/EC of European Parliament and European Council

[7] N. Herisanu, V. Bacria, M. Toader, S. Popa Radovan, "Investigation of noise pollution in an urban area", WSEAS Transaction on Systems, Vol. 7(5), pp.16481653, (2006)

[8] N. Herisanu, V. Bacria, M. Toader, S. Popa Radovan, "Investigation and reduction of ambient noise in urban area", Proceedings of 7-th WSEAS Int. Conference on Acoustics. Theory and Applications, Cavtat, (Croatia), pp.48-53, (2006)

[9] V. Bacria, M. Toader, N. Herisanu, C. Opritescu, V. Ciupa, C. Fiat, "Considerations concerning noise attenuation in urban environment", Proceedings of the IX-th Symposium AVMS Timisoara (Romania), 31 May 2007, pp.7-12, (2007)

[10] Harta strategica de zgomot a Timisoarei", Primaria Municipiului Timisoara, (2008)

[11] Vision 2030 Timisoara metropola europeana, Ed. Brumar, (Romania), (2009) 
[12] V. Bacria and N. Herisanu, "Phonic attenuation due to screen barriers", Analele Univ. Resita, pp.35-42, (2011)

[13] Studiu de circulatie pentru municipiul Timisoara", Primaria Timisoara, (2012)

[14] Protocol privind actualizarea hartii strategice de zgomot a municipiului Timisoara", Primaria Timisoara, (2013)

[15] N. Herisanu, V. Bacria, "The effect of ruberizedasphalt on decreasing the phonic pollution", Appl. Mechanicas and Materials, Vol. 430, pp.257-261, (2013)

[16] V. Bacria, N. Herisanu, "Noise control in an industrial hall", Appl. Mechanics and Materials, Vol.430,pp. 251-256, (2013)

[17] V. Bacria and N. Herisanu, "Action plans for noise prevention and reduction in the city of Timisoara", Facta Universitatis. Series Working and Living Environmental Protection, Vol.12(2), pp.139-149, (2015)

\section{Neki aspekti implementacije akcionih planova za prevenciju i smanjenje buke u urbanim sredinama}

Vasile Bakria $^{1}$, Nikolae Herisanu ${ }^{1 *}$

${ }^{1}$ Mašinski fakultet/Odsek za mehaniku i čvrstoću materijala, Univerzitet Politehnika Temišvar, Temišvar (Rumunija)

Nakon analize mapa buke za drumski, železnički i industrijski saobraćaj na Ldenu i Ln kao i odgovarajućih konfliktnih mapa, pripremljeni su akcioni planovi za sprečavanje $i$ smanjenje buke $u$ navedenim delovima urbane sredine. Oni su odredili mere koje treba preduzeti, datume završetka i broj ljudi koji imaju koristi od smanjenja buke. Za dugoročnu strategiju utvrđene su i mere za smanjenje gradske buke. One su primenjene u Temišvaru. Nakon toga, organi uprave opštine pristupili su sprovođenju mera predviđenih akcionim planovima. U radu je pažnja usmerena na neka razmatranja o njihovoj implementaciji posebno naglašavajući efekte.

Ključne reči: teške mašine, Mašinstvo, Građevinarstvo 